МИНИСТЕРСТВО ОБРАЗОВАНИЯ И НАУКИ РОССИЙСКОЙ ФЕДЕРАЦИИ

СЕВЕРНЫЙ (АРКТИЧЕСКИЙ) ФЕДЕРАЛЬНЫЙ УНИВЕРСИТЕТ

ИМЕНИ М.В. ЛОМОНОСОВА

\author{
ИЗВЕСТИЯ \\ ВЫСШИХ УЧЕБНЫХ ЗАВЕДЕНИЙ
}

\title{
Песной журнал
}

\section{Научный журнал}

Основан в 1833 г.

Издается в серии ИВУЗ с 1958 г.

Выходит 6 раз в год

\section{$3 / 345$}

\section{5}

ИЗДАТЕЛЬ - СЕВЕРНЫЙ (АРКТИЧЕСКИЙ)

ФЕДЕРАЛЬНЫЙ УНИВЕРСИТЕТ ИМЕНИ М.В. ЛОМОНОСОВА 


\section{РЕДАКЦИОННАЯ КОЛЛЕГИЯ:}

МЕЛЕХОВ В.И. - гл. редактор, д-р техн. наук, проф. (Россия, Архангельск) БАБИЧ Н.А. - зам. гл. редактора, д-р с.-х. наук, проф. (Россия, Архангельск) БОГОЛИЦЫН К.Г. - зам. гл. редактора, д-р хим. наук, проф. (Россия, Архангельск) БЕЛЯКОВА Р.В. - отв. секретарь, засл. работник культуры РФ (Россия, Архангельск)

\section{ЧЛЕНЫ РЕДКОЛЛЕГИИ:}

Бессчетнов В.П., д-р биол. наук, проф. (Россия, Нижний Новгород)

Ван Хайнинген А., д-р наук, проф. (США, Ороно)

Воронин А.В., д-р техн. наук, проф. (Россия, Петрозаводск)

Гельфанд Е.Д., Д-р техн. наук, проф (Россия, Архангельск)

Камусин А.А., Д-р техн. наук, проф. (Россия, Москва)

Кищенко И.Т., Д-р биол. наук, проф. (Россия, Петрозаводск)

Кожухов Н.И., д-р экон. наук, проф., академик РАН (Россия, Москва)

Куров В.С., д-р техн. наук, проф. (Россия, Санкт-Петербург)

Малыгин В.И., д-р техн. наук, проф. (Россия, Северодвинск)

Матвеева Р.Н., Д-р с.-Х. наук, проф. (Россия, Красноярск)

Мерзленко М.Д., Д-р с.-Х. наук, проф. (Россия, Москва)

Нимц П., д-р наук, проф. (Швейцария, Цюрих)

Обливин А.Н., д-р техн. наук, проф. (Россия, Москва)

Онегин В.И., д-р техн. наук, проф. (Россия, Санкт-Петербург)

Памфилов Е.А., д-р техн. наук, проф. (Россия, Брянск)

Романов Е.М., д-р с.-х. наук, проф. (Россия, Йошкар-Ола)

Рубцов М.В., д-р с.-х. наук, проф., чл.-корр. РАН (Россия, Москва)

Сакса Т., д-р с.-х. наук, ст. науч. сотр. (Финляндия, Хельсинки)

Санаев В.Г., д-р техн. наук, проф. (Россия, Москва)

Селиховкин А.В., д-р биол. наук, проф. (Россия, Санкт-Петербург)

Сергеевичев B.B., д-р техн- наук, проф. (Россия, Санкт-Петербург)

Сёренсен У.Я., проф. (Норвегия, Стейнхьер)

Сигурдссон Б.Д., Д-р наук, проф. (Исландия, Хваннейри)

Тараканов А.М., Д-р с.-Х. наук, гл. науч. сотр. (Россия, Архангельск)

Хакимова Ф.Х., Д-р техн. наук, проф. (Россия, Пермь)

Холуша О., д-р наук, проф. (Чехия, Брно)

Черная Н.В., д-р техн. наук, проф. (Белоруссия, Минск)

Черных В.Л., д-р с.-х. наук, проф. (Россия, Йошкар-Ола)

Ширнин Ю.А., д-р техн. наук, проф. (Россия, Йошкар-Ола)

Штукин С.С., Д-р с.-х. наук, проф. (Белоруссия, Минск)

Энгельманн Х.-Д., проф., д-р инж. наук (Германия, Эмден)

\section{ЧЛЕНЫ РЕДАКЦИОННОГО СОВЕТА:}

Бабич Н.А. - председатель, д-р с.-х. наук, проф. (Россия, Архангельск)

Билей П.В., д-р техн. наук, проф., акад. ЛАН Украины (Украина, Львов)

Залесов С.В., д-р с.-Х. наук, проф. (Россия, Екатеринбург)

Мясищев Д.Г., Д-р техн. наук, проф. (Россия, Архангельск)

Наквасина Е.Н., Д-р с.-х. наук, проф. (Россия, Архангельск)

Уголев Б.Н., Д-р с.-х. наук, проф. (Россия, Москва)

Хабаров Ю.Г., д-р хим. наук, проф. (Россия, Архангельск) 


\author{
BULLETIN
}

OF HIGHER EDUCATIONAL INSTITUTIONS

\title{
Lesnoi Zhurnal \\ (Forestry journal)
}

\section{Scientific journal}

Established in 1833

Issued as part of the

"Bulletin of Higher Educational Institutions" since 1958

Published 6 times a year

$$
3 / 345
$$

\section{5}

PUBLISHER: NORTHERN (ARCTIC)

FEDERAL UNIVERSITY NAMED AFTER M.V. LOMONOSOV 


\section{EDITORIAL PANEL:}

MELEKHOV V.I. - Editor-in-Chief, Doctor of Engineering, Prof. (Russia, Arkhangelsk) BABICH N.A. - Deputy Editor-in-Chief, Doctor of Agriculture, Prof. (Russia, Arkhangelsk) BOGOLITSYN K.G. - Deputy Editor-in-Chief, Doctor of Chemistry, Prof. (Russia, Arkhangelsk)

BELYAKOVA R.V. - Executive Secretary, Honoured Worker of Culture of the Russian Federation (Russia, Arkhangelsk)

\section{MEMBERS OF THE EDITORIAL PANEL:}

Besschetnov V.P., Doctor of Biology, Prof. (Russia, Nizhny Novgorod)

Van Heiningen A., PhD, Prof. (USA, Orono)

Voronin A.V., Doctor of Engineering, Prof. (Russia, Petrozavodsk)

Gelfand E.D., Doctor of Engineering, Prof. (Russia, Arkhangelsk)

Kamusin A.A., Doctor of Engineering, Prof. (Russia, Moscow)

Kishchenko I.T., Doctor of Biology, Prof. (Russia, Petrozavodsk)

Kozhukhov N.I., Doctor of Economics, Prof., Member of the Russian Academy of Sciences (Russia, Moscow)

Kurov V.S., Doctor of Engineering, Prof. (Russia, Saint-Petersburg)

Malygin V.I., Doctor of Engineering, Prof. (Russia, Severodvinsk)

Matveeva R.N., Doctor of Agriculture, Prof. (Russia, Krasnoyarsk)

Merzlenko M.D., Doctor of Agriculture, Prof. (Russia, Moscow)

Niemz P., PhD, Prof. (Switzerland, Zürich)

Oblivin A.N., Doctor of Engineering, Prof. (Russia, Moscow)

Onegin V.I., Doctor of Engineering, Prof. (Russia, Saint-Petersburg)

Pamfilov E.A., Doctor of Engineering, Prof. (Russia, Bryansk)

Romanov E.M., Doctor of Agriculture, Prof. (Russia, Yoshkar-Ola)

Rubtsov M.V., Doctor of Agriculture, Prof., Corresponding Member of the Russian Academy of Sciences (Russia, Moscow)

Saksa T., Doctor of Agriculture, Senior Researcher (Finland, Helsinki)

Sanaev V.G., Doctor of Engineering, Prof. (Russia, Moscow)

Selikhovkin A.V., Doctor of Biology, Prof. (Russia, Saint-Petersburg)

Sergeevichev V.V., Doctor of Engineering, Prof. (Russia, Saint-Petersburg)

Sørensen O.J., PhD, Prof. (Norway, Steinkjer)

Sigurðsson B.D., PhD, Prof. (Iceland, Hvanneyri)

Tarakanov A.M., Doctor of Agriculture, Prof. (Russia, Arkhangelsk)

Khakimova F.Kh., Doctor of Engineering, Prof. (Russia, Perm)

Holuša O., PhD, Prof. (Czech Republic, Brno)

Chernaya N.V., Doctor of Engineering, Professor (Belarus, Minsk)

Chernykh V.L., Doctor of Agriculture, Prof. (Russia, Yoshkar-Ola)

Shirnin Yu.A., Doctor of Engineering, Prof. (Russia, Yoshkar-Ola)

Shtukin S.S., Doctor of Agriculture, Prof. (Belarus, Minsk)

Engelmann H.-D., Doctor of Engineering, Prof. (Germany, Emden)

\section{MEMBERS OF THE EDITORIAL BOARD:}

Babich N.A. - Chairman, Doctor of Agriculture, Prof. (Russia, Arkhangelsk)

Biley P.V., Doctor of Engineering, Prof., Member of the National Academy of Sciences of Ukraine (Ukraine, Lviv)

Zalesov S.V., Doctor of Agriculture, Prof. (Russia, Yekaterinburg)

Myasishchev D.G., Doctor of Engineering, Prof. (Russia, Arkhangelsk)

Nakvasina E.N., Doctor of Agriculture, Prof. (Russia, Arkhangelsk)

Ugolev B.N., Doctor of Engineering, Prof. (Russia, Moscow)

Khabarov Yu.G., Doctor of Chemistry, Prof. (Russia, Arkhangelsk) 
ISSN 0536 - 1036. ИВУЗ. «Лесной журнал». 2015. № 3

\section{СОДЕРЖАНИЕ}

\section{ЛЕСНОЕ ХОЗЯЙСТВО}

Н.А. Прожерина. Тропосферный озон и его влияние на ранние этапы роста и развития сосны и ели разного географического происхождения

И.А. Юдин, О.А. Юдина, Е.Н. Наквасина. Репродуктивные особенности ели обыкновенной в географических культурах Архангельской области........ 19

B.B. Полякова. Железо в грунтовых и поверхностных водах.................... 29

H.Ю. Сташкевич. Рост Pinus sibirica Du Tour в культурах и под пологом сосновоберезовых лесов в подтаежной зоне Западного Саяна

E.M. Рунова, П.С. Гнаткович. Перспективы рекреационного использования городских лесов селитебной территории Братска

А.И. Смирнов, Ф.С. Орлов, И.И. Дроздов. Влияние низкочастотного электромагнитного поля на прорастание семян и рост сеянцев сосны обыкновенной и ели европейской

С.Н. Марич, Н.А. Бабич, И.М. Бабкин, Ю.Г. Хабаров. Оценка воздействия модифицированных лигносульфонатов на вегетацию сорняков и сеянцев ели в лесных питомниках

МЕХАНИЧЕСКАЯ ОБРАБОТКА ДРЕВЕСИНЫ

И ДРЕВЕСИНОВЕДЕНИЕ

О.Д. Мюллер, В.И. Мелехов, Д.Л. Герасимчук, Н.М. Клюшин, Т.В. Тюрикова. Экспериментальное определение влияния на модуль Юнга давления прессования древесной гранулы.

И.Н. Серпик, А.В. Алексейцев, А.А. Лукаш. Определение параметров пресс-формы для обеспечения целостности лицевой поверхности склеиваемой рельефной фанеры.

A.Е. Алексеев, А.И. Думанский, И.О. Думанский. Выбор режимов лазерной термической обработки ножей рубительных машин для переработки сухостойной древесины.

B.B. Стоянов, А.А. Бояджи. Экспериментальное исследование прочности и деформативности комбинированной металлодеревянной арочной конструкции

\section{ХИМИЧЕСКАЯ ПЕРЕРАБОТКА ДРЕВЕСИНЫ}

А.И. Бубнова, Н.И. Богданович. Получение микропористых углеродных адсорбентов методом термохимической активации хвойных опилок с предобработкой ортофосфорной кислотой на стадии предпиролиза.

T.О. Щербакова, Н.В. Черная. Особенности процесса размола волокнистой суспензии в условиях ее наполнения синтетическими высокодисперсными соединениями в слабощелочной среде. 
ISSN 0536 - 1036. ИВУ3. «Лесной журнал». 2015. № 3

Е.В. Ипатова, С.М. Крутов, И.В. Грибков, Ю.Н. Сазанов. Сольволиз технических лигнинов в водных и спиртовых растворах гидроксида натрия.

КРАТКИЕ СООБЩЕНИЕ И ОБМЕН ОПЫТОМ

C.B. Третьяков, С.В. Коптев, А.П. Богданов. Товарные таблицы для таксации лиственничных древостоев Архангельской области методом круговых реласкопических площадок.

ИСТОРИЯ НАУКИ

E.M. Лупанова. Некоторые аспекты организации и технологий лесного хозяйства в России XVIII в.

ЮБИЛЕИ

Н.А. Бабич, В.И. Мелехов, И.В. Евдокимов. К юбилею ученого-лесовода и поэта А.П. Добрынина.....

И.В. Григорьев. Александр Николаевич Минаев.....

ПАМЯТИ УЧЕНЫХ

H.A. Моисеев. Памяти академика И.С. Мелехова (к 110-летию со дня рождения) 170 


\section{CONTENTS}

\section{FORESTRY}

N.A. Prozherina. Tropospheric Ozone and its Impact on the Early Growth and Development of Scots Pine and Spruce of Different Geographical Origins

I.A. Yudin, O.A. Yudina, E.N. Nakvasina. Reproductive Features of Norway Spruce in Geographical Cultures of the Arkhangelsk Region........................... 19

V.V. Polyakova. Iron in the Surface and Ground Waters.......................... 29

N.Yu. Stashkevich. The Growth of Pinus Sibirica du Tour in Croppers and in Overstorey of Mixed Pine-Birch Forests of Subtaiga Zone in the West Sayan.............. 35

E.M. Runova, P.S. Gnatkovich.Recreational Use Prospects of Urban Forests on Residential Area in Bratsk.

A.I. Smirnov, F.S. Orlov, I.I. Drozdov. Influence of Low Frequency Electromagnetic Field on Seed Germination and Growth of Seedlings of Scots Pine and Norway Spruce.

S.N. Marich, N.A. Babich, I.M. Babkin, Yu.G. Habarov. Impact Assessment of Modified Lignosulfonate for the Vegetation of Weeds and Picea abies Seedlings in Forest Tree Nurseries.

\section{MECHANICAL TECHNOLOGY OF WOOD AND WOODSCIENCE}

O.D. Myuller, V.I. Melehov, G.L. Gerasimchuk, N.M. Klyushin, T.V. Tyurikova. Experimental Determination of the Impact Pressing Pressure of Wood Pellet on the Young's Modulus.

I.N. Serpik, A.V. Alekseytsev, A.A. Lukash. Press Mold Characterization to Ensure the Integrity of the Front Face of the Bonding Relief Plywood.

A.E. Alekseev, A.I. Dumanskiy, I.O. Dumanskiy. Mode Selection of Laser Thermal Treatment of Chipping Machine Knifes for Deadwood Processing.

V.V. Stoyanov, A.A. Boyadzhi. Experimental Study Of Strength And Deformability of Combined Metalwooden Arch Structure.

\section{CHEMICAL TECHNOLOGY OF WOOD}

A.I. Bubnova, N.I. Bogdanovich. Production of Microporous Carbon Adsorbents by Thermochemical Activation of Coniferous Sawdust with Orthophosphoric Acid Pre-Processing at the Prepyrolysis Stage.

T.O. Shcherbakova, N.V. Chernaya. The Features of Fiber Suspension Beating Process under the Conditions of Its Filling by Synthetic Superfine Compounds in Weakly Alkaline Medium

E.V. Ipatova, S.M. Krutov, I.V. Gribkov, Iu.N. Sazanov. Solvolysis of Technical Lignin in Water and Alcohol Solutions of Sodium Hydroxide. 
ISSN 0536 - 1036. ИВУЗ. «Лесной журнал». 2015. № 3

SUMMARIES AND EXCHANGE OF TEACHING

S.V. Tretjakov, S.V. Koptev, A.P. Bogdanov. Commodity Norm for Evaluation of Larch Stands in Arkhangelsk Region by the Method of Relascop Spots. ...

HISTORY OF SCIENCE

E.M. Lupanova. Some Aspects of Forest Management and Technology in Russia of the XVIII Century

JUBILEES

N.A. Babich, V.I. Melekhov, I.V. Evdokimov. The Anniversary of a Research Forester and a Poet A.P. Dobrynin..................................................

I.V. Grigoriev. Alexander Nikolaevich Minayev................................. 168

TO THE MEMORY OF SPECIALISTS

N.A. Moiseev. In Memory of Academician Melekhov I.S. (in the Context of the 110th Anniversary of His Birth) 